\title{
The proliferation of informal sector activities in Congo: Case of the city of Brazzaville
}

\author{
Nzoussi Hilaire Kevin 1, Li Jiang Feng $\underline{2}$ \\ 1. School of Public Administration, China University of Geosciences, Wuhan, 430074 PR China \\ Corresponding Author: Email: nzoussik@yahoo.fr; Tel: 008615527247645
}

\begin{abstract}
The underground of the countries of Africa south of the Sahara is full of enormous potentialities and raw materials of all kinds. But the population of Africa in general and of Africa south of the Sahara, in particular, remains the poorest in the world. A contrast which can be justified by the political and economic instability, the corollary of which is poor management, the drop in the standard of living. The economic potential of these countries does not reflect the level of populations that generally languish in enormous poverty without real livelihoods. Beginning in the 1980s, a largescale economic crisis shook virtually all African countries because of the stringent restrictions and measures imposed by the Bretton Woods institutions, notably the International Monetary Fund and the World Bank. In order to cope with the increasingly difficult living conditions, the populations of which were the main victims, that is to say, the populations will gradually organize themselves and several activities will emerge. These activities are part of the informal sector. It is, therefore, a sector that brings together unemployed people looking for employment and societal well-being who organize themselves to face everyday problems. This means that it is a lucrative sector that is constantly absorbing unemployment in Congo in general and Brazzaville in particular.
\end{abstract}

\section{Key Words}

Proliferation, informal economy, Congo, Brazzaville

\section{Introduction}

The countries of sub-Saharan Africa have very important natural potentialities which are the corollary of their immense fauna and flora, as well as of the very varied soil and subsoil. However, the economic evolution of all these countries does not very often reflect the standard of living of their populations because of poor management of resources and poor distribution of wealth. Nearly $70 \%$ of their population lives below the poverty line. This figure is not uniform and may vary across countries due to their disparity. The Republic of Congo otherwise known as CongoBrazzaville, to differentiate it from its neighbor the Democratic Republic of Congo or Congo-Kinshasa did not remain on the margin of this situation. Beginning in the 1980s, a large-scale economic crisis shook virtually all African countries because of the stringent restrictions and measures imposed by the Bretton Woods institutions, notably the International Monetary Fund and the World Bank. In order to cope with the increasingly difficult living conditions, the populations of which were the main victims, that is to say, the populations will gradually organize themselves and several activities will emerge. These activities are part of the informal sector. In other words, the populations of the Congo in general and those of Brazzaville, in particular, are organized in one way or another, each in its own corner; its land creates the means of its survival. The interest of the people themselves who are astounding by their creativity and their capacity for innovation in the design of flexible instruments adapted to the socio-cultural context for the collection of savings and its productive and/or social affectation. (Kane, 2010). Obviously, implicit in the 1970s, the informal sector has grown to the point where it even competes with the so-called formal sector. The divisibility of products, and their evolutionary demand due to the weakness of their purchasing power is a factor that strengthens the seller/buyer relationship. This relationship, beyond its economic function, favors an absence of conviviality in the formal sector where prices are not negotiated (Shomba, 2004). In Congo-Brazzaville, and particularly in the capital city of Brazzaville, the deterioration in purchasing power, the delay in paying civil servants salaries, and the rise in prices of basic necessities in the market have pushed many households to carry out certain activities related to the informal sector, in order to cope with the new living conditions and the urban problems facing them.

As mentioned above, structural adjustment programs, downsizing of civil servants, decreasing wages, nonrestructuring of public enterprises, the government's inability to clear the external debt, not resumed negotiations with the institutions of Breton woods ... have boosted the informal sector. Some of them exercised in the formal sector which saw its influence reduced more and more to the benefit of the informal which has grown in numbers. The informal and formal sectors are therefore closely linked, it would be only by the currency of which they make common use. The informal thus acts both as a safety valve and as a buffer against social shocks (Savane, 2002).

While the informal sector and the informal economy generate enormous benefits, it is important to note that the consequences of this saving and lucrative activity are significant. This is justified by the fact that workers do not benefit from social protection, consumers have no guarantee ... Companies have to face unfair and detrimental competition on the part of those Which do not comply with general tax and social obligations. (Economie souterraine, 1999). The objective of this article is to identify the origins of the informal sector and its place in the lives of the people of Brazzaville. 


\section{Study Area}

Brazzaville is bordered by the Congo River; it is the political and administrative capital of the Republic of the Congo, therefore, the seat of the administrations and the power.

It is located on the right bank of the Congo River. Brazzaville had an area of $110 \mathrm{~km} 2$ in 1980 for a population of 420000 inhabitants (CNSEC). It is a city that covers nearly 20.000ha and extends inordinately (Moundza, 2006). Its population increased from 760,000 in 1990 to 1,373,382 in 2007 (Yekoka, 2008). The city is an autonomous administrative department, separated from the other regions of the republic; it is surrounded by the pool area. Around the town is a large savannah. The city is relatively flat and located at an altitude of 317 meters $(1,040$ feet). The city has an area of $263.9 \mathrm{~km} 2$ with a population of 1.373 .382 inhabitants (2007)), and a density $5204 \mathrm{hab} / \mathrm{Km} 2$.

Today, of the 4500000 million inhabitants of the Congo, Brazzaville alone has 1700000 inhabitants (Statistics 2015). Its influence is, therefore, incontestable and constitutes a macrocephalic city (Nzoussi, 2017).

\section{Definition of concepts}

Proliferation is the multiplication or rapid increase of such and such a thing. In other words, is the reproduction of something in abundance in a given environment (1). As part of this study, it is the rapid multiplication of non-formal activities throughout the city of Brazzaville.

Concepts related to the informal economy will be developed throughout this work. "In reality, in the word of the usual language, as the concepts they express, are always ambiguous and the scientist who uses them as he receives them from the user without making them undergo further elaboration would expose himself to the most serious confusions (Dukhreime, 1973).

According to the dictionary petit Larousse, the informal sector is a sector which does not obey certain rules and which does not have an official character (Larousse.2011).

In 1972, the International Labor Office (ILO) published the state of employment in Ghana and Kenya, recognizing the existence of activities that were not part of either the traditional sector or the modern sector. The economy, their naming of this fact was not unanimous by the authors who were addressing the issue. Thus, it was the recognition and the starting point of the so-called informal sector activities. Also, several qualifiers and appellations were given to this sector.The informal economy, underground economy, informal sector, marginal sector, informal economy, unregulated economy, undeclared economy, occult economy...(Macgaffey, 1993).Other authors who defined this concept the example of $\mathrm{H}$. Jospin, $\mathrm{M}$.

Label the unstructured sector. However, the notion of the informal sector was introduced and accepted by everyone in 1972. That was K.HART who had used it for the first time (Turnham et al., 1990).

In the informal sector, the three types of activities are necessarily represented. These are tontines or traveling banks, repair shops and traditional medicine.

Obviously, alongside these five main sectors of activity, linked to the evolution of science and technology, notably the primary sector, which is that of core activities, the secondary sector linked to the transformation of the sector's activities primary sector which is favorable to industry and the economy, the tertiary sector, which is the domain of administration and services, are the Quaternary sector related to automation, chain work, haste and sector the space shuttle launch and the exploration of other planets. Finally, there is a new informal sector.

That is to say, there is a whole bunch of definitions. It is, therefore, difficult or impossible to give an overall definition of this concept, and each author and in philosophy defines the informal sector according to his vision, his conception and his way of conceiving things. Nevertheless, everyone agrees the fact that this sector is not formal.

The informal sector in a defining way is protected by barriers that hinder and/or impede access to it, so the informal sector is characterized by freedom of access to its activities (Fields, G. 1990). The informal sector encompasses activities that are more or less outside the law and official institutions and that have norms and values that are specific to those of modernity. Moreover, they are atypical, composite and ambiguous cultural forms which underlie practices and institutions that are indifferent or rebellious to the formally legitimate legal and institutional framework (Villers G., 1999).

In general, any economic activity that is beyond the control of the State through its services (police, customs, tax, etc.) can be described as informal. This sector has grown more and more in countries struggling to lift their populations out of poverty and has a strong presence in countries in Southern Asia, Central and South America and Africa. Congo Brazzaville, a highly indebted poor country in relation to the status assigned to it by the international monetary institutions (IMF and WB) respectively International Monetary Fund and World Bank, although rich in (oil, wood, iron, zinc, Lead, etc.), is also part of those countries where the informal sector has grown throughout the country in general, and in Brazzaville in particular, which is the subject of our study. 
After reviewing all these definitions related to the informal sector, it is a matter of studying mutual's and tontines or embalming banks, as they are the corollary of the development of informal activities. But above all, it is important to make a reminder of the origins of this sector in Brazzaville.

\section{The Origins of the Informal Sector in Congo}

"Most people take informal occupations. The informal sector includes specific standards and values for modernity. Moreover, they are atypical cultural forms that favor practices and institutions that are indifferent to the legal and institutional framework" (Villers, 1999).

The informal sector has existed for a long time in the city of Brazzaville. It was practiced on a small scale by foreigners from neighboring Congo, during the modernization of the city of Brazzaville around the 1960s and 1970s. Congolese from the Democratic Republic of the Congo (DRC), Of the CAR (Central African Republic), and some West Africans. But in the late 1990s, a major economic crisis was raging in the Congo. The crisis was due to fall commodity prices, particularly oil, and the main source of income for the country. To this are added drastic measures imposed by the IMF and the World Bank in the Congo. Faced with these major financial difficulties, the Congolese in general and the people of Brazzaville, in particular, embarked on the activities of the informal sector. Today, this sector is very flourishing and growing.

\section{Popular practices}

\subsection{The mutuals}

Etymologically speaking mutual comes from the Latin word " mutuus ", which means that mutual or exchange. The mutual society is a non-profit association that offers its members, belonging to the same professional branch. It is, therefore, an insurance or voluntary pension system (2). Since more than two decades mutually abounds in the city of Brazzaville. The populations organize themselves in different districts, boroughs and help one another. These mutuals are mostly visible during mourning vigils and disease situations.

It should be noted that the difficulties of access to care and the explosion of the cost of living have pushed people to reflect on the new modes of social and community organization closer together. Each member obeys certain rules and pays monthly. The mutual fund is held by one of the members. This form of tontine is also hierarchies at the head of which is first a president of the mutual then his collaborators and finally the members. The different members even have collective outfits of the same color above which there is sometimes an effigy symbolizing cordial understanding and unity. They are the mutual's in markets, administrations, churches...

\section{The tontines}

Tontines are a joint financial arrangement whereby participants usually also contribute to a price that is entirely attributed to the participant that survives all other (3).It also an operation in which more people as the payment of a contribution common fund to be capitalized and paid at maturity agreed to survivors (4). It, therefore, a form of cooperation.

To understand the dynamism that characterizes tontines today in popular circles (...), it is essential to locate their anchoring in the millennial practices of reciprocity and sociability whose relations of kinship and neighborhood constitute the main supports (Kane, 2010). Tontines were practiced even in traditional African societies long before the introduction of currency. This is what some authors claim (Henry, A., Tchente, G.H, Guillerme-Dieumegard, P. 1991, Essombe Edimo J.R, 1995, Mayoukou C., 1996). They all speak of labor tontines in pre-colonial Africa, which have gradually transformed with the introduction of money into silver tontines (Kane, 2010).

In short, the absence of banks and micro-finance capable of giving credits and consequent help to the populations in the undertaking of their projects and lucrative activities pushed the latter to develop this community space of mutual assistance in which one Finds populations of all social categories. We can mention the civil servants, the traders, the unemployed, the hustlers...

\section{Some informal sector activities}

\subsection{The profile of some practitioners}

The world is increasingly urbanized, with half of the world's population living in cities and urban areas. This figure of 50 per cent is expected to rise to 70 percent by 2050 (UN-Habitat, 2008). There is, therefore, an influx of people to the city in search of well-being. In Brazzaville, many neo-city dwellers and even natives of the city indulge in the activities of the informal sector through lack of employment. The profiles of these young people who engage in these kinds of activities are mainly those who are struck by unemployment and those who are looking for employment. Among those who have idlers, students, children of school age, young people who have lost their jobs... 
However, there are also some populations that practice there to cope with everyday problems and especially to join the two ends of the month. Note that Brazzaville is among the expensive cities in Africa and occupies 12th place (Nzoussi, 2014c).

The Republic of Congo, otherwise known as Congo-Brazzaville to differentiate it from its neighboring Democratic Republic of Congo or Congo-Kinshasa, is a country where the population lives in the two large metropolises of which Brazzaville has 1700000 inhabitants (Nzoussi 2017). This country has known (Ngakoli, 2014). Despite the commitment made by the State in the context of the Millennium Development Goals (MDG) to reduce 2015 by half poverty, the results have not been achieved. Until now, $70 \%$ of the population lives below the poverty line with less than $1 \$$ per day (considered as the poverty line). The 2014 World Bank report shows that $50 \%$ of the country's urban population lives below the poverty line, compared with $75 \%$ in rural areas. This places the country in 136 th place out of 182, according to HDI (Human Development Indicator) and UNDP (United Nations Development Programme).

\subsection{Washing cars}

This activity of the informal sector is truly growing in the city of Brazzaville in general, and in the southern districts in particular. During the hostilities known to the Congo during the years 1993-1997 and 1999, the southern districts of Brazzaville were much affected by the war compared to the northern districts of the city. Also, the department of the pool near Brazzaville was badly damaged by the aforementioned wars, a bastion of the former rebels. In 1993-94, in the summer of 1997 and at the end of 1998, three bloody "militia wars" accompanied by increasingly systematic pillaging and criminal violence first ravaged the Congolese capital before spreading to the south of the country. The young militia majority, aged between 18 and 22 years, was undoubtedly the object of manipulation, all the easier because it was carried out at a time when the economic collapse succeeding Years of petroleum euphoria forbids them virtually any hope of reaching the social status of their elders (Dorier Apprill et al., 2006).

This is why, since the return of peace, to the social life, and the almost missed operation of DDR (Disarmament, Demobilization, and Reintegration) ex-combatants, these, as well as unemployed populations, Organize themselves for survival in urban areas.

The washing of cars is, therefore, experiencing considerable growth and constitutes, as much as possible, an activity in the informal sector. This activity includes many young idlers, aged between 15 and 40 years. Some may use public pavements to undertake their activities since space management is also a problem in Brazzaville. They take advantage of this urban disorder. Others use parcels of land that are not yet developed. The cost of washing a car is 300XAFor 4 or 5 USD for small cars and 500fca or 8 or 9 USD for large vehicles respectively.

This car-washing activity makes it possible to feed many families in Brazzaville where $70 \%$ of the population lives below the poverty line. The current economic crisis in the country due mainly to the fall of the oil barrel, the country's main economic resource leaves several families in disarray.

In short, informal activities in general and car washing, in particular, have become a non-negligible lucrative source of the populations which continue to organize for the survival in urban Brazzaville.

\subsection{Phone booths}

This is an informal activity in which there are many students, schoolchildren, and children who are not yet of working age but also other young people. It is a real environment of refuge which makes it possible to reduce unemployment. Society has created a categorization of jobs, and the development of self-supporters, that is to say, children and adolescents who take care of themselves. Telephone booths are usually installed along alleys and avenues. We also find mobile cabins. This has to develop the work of the child before its maturity, because during the periods of great holidays, we witness the practice and the proliferation of this banal service of execution as the telephone booths and The sale of charging cards, as well by minor children who are sometimes school children in search of funds to prepare the next school year, but also students who have great difficulty to deal with urban life.

Indeed, phone booths allow them to support their parents in preparing school or academic year. But, it should be noted that there are all the categories of the young, the scholars and the others. It is often during the period of school holidays that school children are abundant in this sector of activity. They take it as a holiday yard. And as for other young people, this is a profitable business that must be perpetuated, some have already chosen as their economic activity given financial autonomy and socio-economic integration it causes (5).

\subsection{The guards}

This activity is managed in Brazzaville by two companies recognized by the State. These are First Security and SCAB, whose monthly salary varies between 60 and 80,000XAF, or 120 to 140 USD. Apart from these two companies, guarding is also carried out informally. As in any developing country where social cleavages are strongly pronounced, persons belonging to the privileged class recruit artisanally persons of good faith to provide this service, especially at night, when growing insecurity prevails. This insecurity is due both to the obscurity which is itself the cause of the load shedding, to the difficulties of access to certain districts, to the turning points common to poverty 
but more recently to the increase of the phenomenon of "Black babies" (highway bandits). As a result, wealthy families protect themselves by recruiting people in good faith. It is generally adults, job seekers, and students who engage in these activities.

Clearly, this informal activity poses many risks to its practitioners, because no legal text binds those who recruit and those who work. It is, therefore, a contract by mutual agreement. This is justified by the fact that many of the guards are victims of aggression and sometimes even targeted assassinations

\subsection{Parking}

Each and every one traces his family paths in the city, certainly more or less vast and dense according to the agglomerations and the knowledge that he or she has of them, but always indispensable to be able to simply live there. Whatever the material forms it is called upon to take, this familiar dimension of the city is an essential part of the city life, it is this which allows the minimal social anchoring of each one, its vital social minimum, such as 'It is lived in the most minute details of everyday life (Agier, 1999).

In Brazzaville, no law regulates the management of car parks and is just similar to the activities of the informal sector. Like any activity in the informal sector, parking management does not allow the state to levy taxes. However, the state recognizes this, as shippers and car park manager's work in collaboration with state representatives, police officers, and city council officials. Shippers and managers are generally socially excluded people, i.e. persons who have failed to achieve social integration, and ex-combatants who, after abandoning the rebellion, have converted into a driver or shipper. Bus or car park sweeper. Informal activities are all a particular form of social dynamics in developing societies. They are a response to society to new needs, structural changes, social constraints resulting from the influence of development transfers on all social categories (Penouil, 1978).

Like all informal activities, the management of car parks constitutes a shortfall to the State, which is nevertheless a player in the management of markets and regional planning. The collected and collected taxes go directly into the pockets of individuals. The informal thus acts both as a safety valve and as a buffer for social shocks (Savane, 2002).

Obviously, the scarcity of work, the closing of the labor market, the exclusion of young people in several decisionmaking bodies obviously lead some to find themselves in the world of car parks or they feed their families little.

In China, the organization of transport, as well as the management of car parks, is regulated by the providential state, which exercises an authoritarian power. He manages public transport, recruits workers, and surface technicians. However, in Congo Brazzaville in general and Brazzaville in particular, the populations organize themselves. The state just stops at the regulation of taxes, and other transport support.

\subsubsection{Social Economy and Associative Initiatives}

The informal sector has enabled the population to develop strategies more adapted to social and community life. This booming sector continues to see its workforce increase due to the closure of the labor market, but also the current economic crisis in the Congo in general and its capital city in particular. That is why, the Survival, parallel economic transactions, unregistered at the state level, much more social anchoring (..) aim to ensure the daily minimum subsistence with mechanisms of redistribution of a purely social nature. These activities are more concentrated in urban areas, but also in rural areas (Ngouari, 2005). Most Third World countries that are seeking to emerge can no longer do without this very lucrative and unavoidable sector. The informal economy is undoubtedly the social economy (...), this is undoubtedly the reason for the more widespread introduction of new models of economics (Genilas, 1994).This sector is one of the areas that could contribute effectively to the country's economic growth in the coming days.

Indeed, evolution and development are not only economic but also social. And all sectors of activity are virtually important to contribute to the socio-economic development of the country. We cannot consider development solely as an economic issue, but as a social process as a whole, which depends on the outcome of man's struggles with his natural environment (Rodney, 1986).

\subsection{The economic impact}

Over the past two decades, informal activities have seen a strong explosion and are contributing effectively to the social economy. The promotion of the informal sector is now one of the main subjects of development policies (Maldonado, 1999).) If the informal economy has reached such proportions that almost three-quarters of Brazzaville populations depend on it, is that this form of economy has become essential in the face of the state inability to meet the basic and vital needs of the population through the so-called formal economy (Ngouari, 2006). The informal economy contributes to SME (Small and Medium Enterprises), which themselves are struggling to develop further due to archaic methods, lack of means and products imported from neighboring countries but also from China. The informal sector also contributes to the opening of micro Finances.

However, this sector has negative consequences and constitutes a shortfall in the state because of the lack of the legal framework to regulate such a flourishing sector. This is due to child labor, which is increasing in Brazzaville, 
which lacks protection, despite the treaties and conventions signed by the Congo and UNICEF (United Nations Children's Fund). Finally, this sector increased bribery, corruption, and fraud.This is especially true because people are paid in cash that is upon hand.

\section{Conclusion}

This article aimed to show the origin of the informal sector and its place in everyday life and the economy of the country. Before a job market reduces an economy struggling to be diversified and to get up in Congo Brazzaville in general and Brazzaville in particular, the informal sector is increasingly recognized and now occupies a significant place in the urban life Brazzaville and the economy of the country in particular. These informal sector activities that are part of the social economy are taking place in almost all areas of global society: finance, food, transportation, housing, community, factory culture, health, social service and advocacy for the person etc (Mendell and Levesque, 1999; Malo and Mareau 1999, Defourny, Favreau and Laville, 1998). It is provided that in the coming years, this sector will be increasingly growing. However, it is important for the State to reserve a prominent place in this lucrative sector by putting in place: a legal framework that will be used to officially recognize the sector and protect the practitioners. Accompany and Multiply banks and microfinance to the example of MUCODEC (Congolese Mutual Savings and Credit) born in 1984 who should grant small loans to people with.Government projects must, therefore, ensure social security to people in the informal sector, which must first contribute and pay a portion of their monthly income in banks or micro quality finances, able to handle the short, medium and long term their savings and contributions and distribute them retirement.

\section{Acknowledgements}

I thank Professor Li Jiang Feng for his expertise and experience in supervising this scientific work. My thanks also go to the place of my parents and friends and acquaintances that constantly bring me their multifaceted competition. That anyone who has helped me and has not been quoted here is an expression of my sincere thanks.

\section{References}

1. Agier M., 1999, The invention of the city. Suburbs, townships and shantytowns, Paris, ed conditions of contemporary archives, $176 \mathrm{p}$

2. Defourny J.et al, 1998, Inserting and new social economy.An international balance sheet, Paris, Desclee Brouwer.

3. Dorrier Apprill E. et al, 2006 living in Brazzaville, modernity and everyday crisis, Paris, Karthala 383p

4. Dorrier Apprill E., 2000, The role of politics in urban and territorial breakdown, the case of the Congo "in territorial policies and dynamic in the southern countries, the publications of the SorbonnePRODIG, pp 155-170

5. Durkheim E., 1973, Suicide, Paris, PUF

6. Economie souterraine (1999), Annual Report DGCCRF

7. Essombe Edimo, J.R, 1995 "Financial Dynamics tontine. What lessons for financing small businesses in Africa, Revue Tiers Monde, T.XXXIX, No. 156, pp.861-83.

8. Fields G (1990) quotes by Thomas JJ summary of comments and discussion: methodology and theory in new approaches to informal sector OECD, Paris, P.103

9. Gelinas, Jacques B., 1994, If the Third World was self-financing: From debt to savings, eco Publishing Company, Montreal, $238 \mathrm{p}$.

10. Henry, A .; Tchente, G.H .; Guillerme-Dieumegard, P., 1991 Tontines and banks in Cameroon, Karthala, $166 \mathrm{P}$

11. Kane A., 2010, Tontines, solidarity funds and street bankers, Paris, L'Harmattan, 251P

12. Levesque B et al. ,1999, Social Economy in Quebec: a theoretical and empirical element for debate in search, social and political link n 0 41.105-117.

13. MacGaffey J., 1993. It is doing: thinking about the second largest economy in Zaire, P.144

14. Maldonado C. et al., (1999, The informal sector in Africa face the legal and institutional constraints, ILO, Geneva, 367P

15. Malo M.C et al., 1999, Community Economic Development Corporation CDEC and Desjardins caisse: what partnership configuration in the Social link and -RIAC policy, n0 41, P.119-127?

16. Mayoukou, C., 1996, "The reputation, an incentive mechanism in the intermediation function of tontiniers Sub-Saharan Africa". Networks for Research on Entrepreneurship AUPELF- UREF Research Note nำ6-57, $19 p$.

17. Ngakoli. E.V., 2014, Economic growth and poverty; pro-poor growth? In the republic of Congo in Theoretical Economics Letters (TEL); Vol 4 (6) (e-ISSN2162-2086) P.473-476

18. Ngouari A.A, 2005, Informal Economy, and practices in Congo Brazzaville: situation and prospects, Montreal, Cahiers du LAPEPPS, n 0 05-09, UQAM, 40p

19. Ngouari A.A., 2006, Social Policy and Development: The Case of Congo Brazzaville, master's thesis, University of Quebec at Montreal, 158P 
20. Moundza P., 2006, The market: refueling places and alternatives to inactivity in Brazzaville, a city rebuilt, Paris, Karthala p 225-234

21. Nzoussi H.K., 2017a, Urban Governance and Quality of Life in Brazzaville, Ph.D. Thesis, China University of Geosciences, Wuhan (Ongoing Ph.D. Thesis).

22. Nzoussi HK (2017b) Pragmatic approach to the construction and reinvention of cities in developing countries: the case of Brazzaville in the Republic of Congo, Journal of Social Sciences Research (JSSR).Vol 11(2).ISSN:2321-1091,P2281-2291

23. Nzoussi HK (2014a), Economic and social contributions of parking in Brazzaville, a case study of total Bacongo Market in International Journal of Science and Research (IJSR); Vol 3 (7), (e-ISSN; 2319-7074) p384-386.

24. Nzoussi $\mathrm{H} \mathrm{K}$ and al, 2014c The issues of residential mobility in the case of the Congo city of Brazzaville, American Journal of Educational Research (AJER) Vol.2 N0 10 (eISSN, 2327-6150), p.906-910

25. Penouil M., 1978 preface in P. Mettelin Schaudel and under the direction of, " the transition activities and the informal sector in Abidjan, Bordeaux, CEAN, African Economic Research

26. Rodney W. 1986. And Europe Underdeveloped Africa, historical and political analysis of underdevelopment, Ed. Caribbean's, Paris, 293p

27. Savannah, I, 2002, informal that's life, in http: www.africaoline.co.ci / 28.02 in 2002 Africa online / info / frat mat /

28. Shomba L., 2003. The promotion of the informal economy in Congolese law: what option is exercised between it's reformed and its formalization, Master Thesis, University of Kinshasa, $81 \mathrm{p}$

29. Turnham D et al. 1990 The Informal Sector, OECD, Paris, p.13

30. Villers G., 1999 Informal Sector in Congo-Kinshasa, strategies for endogenous development è not, USA, pp 35-36 Kinshasa

31. Yekoka F., 2008, spatial practices and urban imbroglio in Brazzaville, analysis of public administration dysfunction of space Condersia

\section{Websites}

1. https: //fr.wikipedia.org/wiki/Proliferation

2. http: //www.toupie.org/Dictionnaire/Mutuelle.htm

3. https: //www.merriam-webster.com/dictionary/tontine

4. http://www.larousse.fr/dictionnaires/francais/tontine/78426

5. http://www.adiac-congo.com/content/secteur-informel-les-cabines-telephoniques-rendent-denormesservices-aux-jeunes-55808 